\title{
Finding of No Significant Impact Resumption of Thermal Stabilization of Plutonium Oxide in Building 707
}

U.S. Department of Energy

Rocky Flats Plant

Golden, Colorado

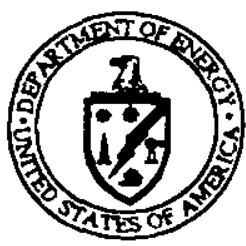

February 1994 


\section{FINDING OF NO SIGNIFICANT IMPACT \\ RESUMPTION OF THERMAL STABILIZATION \\ OF PLUTONIUM OXIDE IN BUILDING 707 \\ AT THE ROCKY FLATS PLANT, GOLDEN, COLORADO}

AGENCY: Department of Energy

ACTION: Finding of No Significant Impact

SUMmaRY: The Department of Energy (DOE) has prepared an Environmental Assessment (EA), DOE/EA-0887, for the proposed thermal stabilization (contro rèd oxidation) of pruconium, to rake place in but aing $\mathrm{Ni}$, Rocky Flats Plant, Golden, Colorado. The stabilization action would include post-stabilization characterization and on-site movement of stabilized material. Public meetings were held on July 7 and October 6, 1993, to discuss the scope and analyses in the EA. The scope of the EA included evaluation of alternative methods of stabilization, stabilization in other buildings at Rocky Flats, shipping off-site for stabilization, and no action. The public and the State were provided 60 days to comment on the $E A$, and comments received were responded to as needed in the final EA. Based on the analyses in the EA, DOE has determined that the proposed action would not significantly affect the quality of human environment, within the meaning of the National Environmental Policy Act (NEPA) of 1969. Therefore, the preparation of an Environmental Impact Statement is not required and the Department is issuing this Finding of No Significant Impact. 
FOR FURTHER INFORMATION, CONTACT:

Beth Brainard-Jordan

Director, Office of Communications

U.S. Department of Energy

Rocky Flats Office

P.0. Box 928

Goiden, C0 80402-0928

The document may be reviewed at DOE Rocky Flats Public Reading Rooms:

- Front Range Community College Library, Westminster, Colorado

- Council on Rocky Flats Office, Golden, Colorado

- U.S. Environmental Protection Agency's Superfund Records

Center, Denver, Colorado

Other Sites:

- Colorado Department of Health offices, Denver, Colorado

- Standley Lake Library, Arvada, Colorado

- Department of Energy's Freedom of Information Office, Washington, $D C$.

For Further Information on DOE's NEPA Process, Contact:

Caral Borgstrom

Office of NEPA Oversight, EH-25

U.S. Department of Energy

1000 Independence Avenue, S.W.

Washington, DC 20585

Phone: (202) $586-4600$ or (800) 472-2756

\section{SUPPLEMENTARY INFORMATION:}

Background: Thermal stabilization is the term used to describe controlled heating of incompletely oxidized plutonium, converting the plutonium to a relatively inert, non-combustible form for storage. Incompletely oxidized plutonium is a result of natural (but incomplete) oxidation of plutonium metal surfaces when exposed to oxygen, water vapor, or other reactive substances. These plutonium oxides are fine powders that form on the surface of metallic plutonium. The fine powder is potentially pyrophoric (that is, it may spontaneously ignite if environmental conditions are appropriate), so careful attention to 
conditions for storage of such materials is required to prevent ignition. The fire hazard associated with potentially pyrophoric plutonium can be removed by completely oxidizing the plutonium in a controlled heating process, the process termed thermal stabilization.

Plutonium oxides are collected during routine material management activities (such as brushing off and collecting the powdery oxide from stored plutonium) that are required to maintain safe storage of plutonium metal. This potentially pyrophoric plutonium will continue to ho formod and thormal ctahilization will ho noodod ac lnnn ac

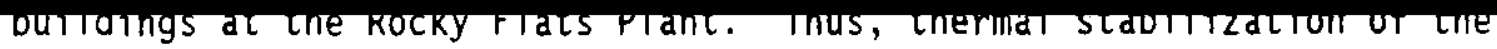
partially oxidized (potentially pyrophoric) plutonium was a routine activity associated with plutonium management at Rocky Flats for more than 20 years, up to 1989 .

In 1989, fabrication of weapons components from plutonium ceased, and routine operations concerning plutonium were curtailed at Rocky Flats Plant. Since then, an inventory of approximately 100 pounds of potentially pyrophoric plutonium has accumulated. Additional potentially pyrophoric plutonium will form and be collected by Rocky Flats personnel as long as plutonium is stored at the Rocky flats Plant. Thermal stabilization would therefore enhance safety during interim storage of plutonium at Rocky Flats; it would not promote weapons production-related activities. 
The quantity of potentially pyrophoric plutonium requiring stabilization in any year is projected to be less than 440 pounds. This upper-bound estimate is based on uncertainties in the amount of potentially pyrophoric plutonium requiring collection during inspections, and uncertainties in the amount accumulated since operations were suspended in 1989. However, once this backlog of potentially pyrophoric plutonium is stabilized, the amount of plutonium to be processed each year would be well below 440 pounds per year.

Public Participation: Substantial public interest in the proposed action led DOE to hold public hearings to discuss the proposal. During preparation of the EA, the Department held two public meetings, July 7 and october 6,1993 . At the July meeting, the scope of topics to be addressed in the EA was discussed, along with other matters of interest to the public. The Department agreed with public requests, made at the July meeting, for a 60-day public review of the EA in draft form, instead of DOE's usual 14-to 30-day pre-approval review of the draft EA by only the affected State(s) and Indian Tribes.

The October meeting was held in the midst of the 60 -day review period, to allow discussion and clarification of any questions arising from the public review. Following the public review, the EA was revised as needed to respond to comments received from the public and the State. In addition, a detailed Response to Comments document was prepared for the EA. 
Two general types of comments were received from the public reviews. One type dealt with the larger questions regarding the need for nuclear weapons, and with the weapons complex in general. These comments did not require specific revision of the EA. However, five issues arose repeatedly in the public comments, leading in some cases to revision of the EA. These issues were (1) ultimate disposition of the plutonium; (2) safety at Rocky Flats Plant; (3) the total amount of potentially pyrophoric plutonium to be stabilized; (4) whether thermal stabilization is an incineration process; and (5) whether excess plutonium must be declared to be waste.

The EA was revised to provide additional background on the changing need for the plutonium, in the Purpose and Need section of the EA. The

Intent, published July 23, 1993. The EA was also revised and augmented to provide additional materials on safety in the proposed Building 707 operations, as well as other buildings at Rocky Flats Plant. The EA was further revised to include more information regarding the amount of plutonium to be stabilized, its source, and its treatment. Other public comments led to specific revisions, such as a concrete definition of "near term," and the addition of another alternative treatment to be considered (lower temperature stabilization using chemical catalysis). 

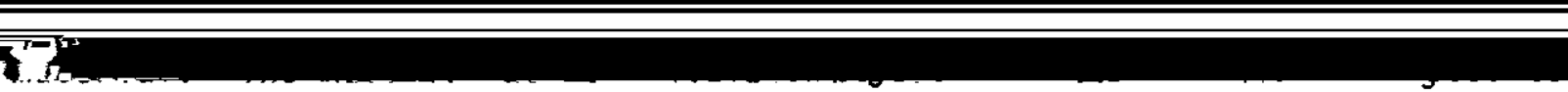

to $500{ }^{\circ} \mathrm{C}$, and samples of the stabilized material would be sent to Building 559 for analysis to verify complete stabilization and to verify that it was non-pyrophoric. The stabilized material would then be packaged, analyzed for nuclear material contents, and moved into storage in vaults or vault-type rooms.

Movement of plutonium between buildings at Rocky Flats would occur through connecting tunnels and enclosed passageways, or via truck. Material would be packaged in double cans and placed in a specially designed cart to travel through a tunnel or passageway between buildings, or in a Type 6C, ten-gallon drum placed on a truck, for buildings not connected by passageways. Truck routes would be closed to normal traffic during on-site movements. 
Environmental Impacts: Under routine operation, thermal stabilization would result in a collective worker exposure of about 14 person-rem per year. On-site transportation would yield another 7 person-rem per year exposure to the workers. This dose would typically be distributed among about 25 workers. Overall, the proposed action would be expected to induce a latent cancer fatality (LCF) with a probability of about $9 \times 10^{-3}$, using the National Research Council risk factor for induction of fatal cancers of $4 \times 10^{-4}$ per person-rem for workers.

The estimated maximum dose to a member of the public under routine operations would be about $3 \times 10^{-9}$ rem per year. This corresponds to induction of a fatal cancer with probability of about $2 \times 10^{-12}$, using the NRC risk factor of $5 \times 10^{-4}$ for the general public. ${ }^{1}$

Under accident conditions, a reasonably foreseeable (but extremely unlikely) accident involving criticality would lead to fatal exposures for an unknown but small number of workers (probably one worker). Another reasonably foreseeable but very unlikely accident would be a fire during transport of plutonium between buildings; such an event would yield exposures to the worker(s) involved of about 500 to 700 rem cumulative estimated dose equivalent. This level of exposure would be associated with odds of inducing a fatal cancer ranging from about five to one against any cancer, up to induction of two cancers in the

\footnotetext{
${ }^{1}$ The risk factor for the general public is somewhat larger than that for workers because of the presence of children in the public population.
} 
worker(s) involved (if lethal radiation sickness were not induced). Other foreseeable accidents are bounded by these two.

Under accident conditions, a bounding accident for public exposures would be a severe transportation accident in extremely unfavorable meteorological conditions. The total potential exposure to the entire population within 50 miles was estimated to have a maximum effect of inducing about three cancers in the entire population; the same accident scenario, but taking place in average (not extreme) meteorological conditions, would be expected to have odds of about three to one against any cancer. Odds against such an accident occurring at all, regardless of meteorological conditions, are estimated to lie between 10,000 to one and a million to one.

The peak collective worker dose due to normal inspection and surveillance activities under the no-action alternative would be significantly larger than under the proposed action. Under the noaction alternative, the collective worker dose was estimated to be approximately 171 person-rem per year, beginning about a year after the decision to take no action. Of that 171 person-rem, approximately 147 person-rem would be attributable to 24 -hour surveitlance of pyrophoric plutonium storage at levels above the Nuclear Material Safeguards Category III limits for each building. Once begun, this surveillance would be continuous at each building under the no-action a)ternative until all the material in each building was stored in Building 371 . 
Thermal stabilization activities would not be expected to have any effects on local ecosystems on or around Rocky Flats, since activities would be conducted within existing buildings.

Thermal stabilization would generate low-level or transuranic waste, with the potential for generation of small quantities of mixed waste. Annual estimated waste quantities generated during the period of maximum processing would be approximately 12 cubic yards. Any waste generated would be managed in accordance with all applicable requirements until removal from Rocky Flats.

Alternatives Considered: DOE considered the following alternatives to the proposed action of thermally stabilizing potentially pyrophoric plutonium in Building 707: no action, thermal stabilization in other buildings at Rocky Flats, alternative processes for stabilizing pyrophoric plutonium, and shipping pyrophoric plutonium off-site.

The no-action alternative was determined to be unacceptable, since the hazard posed by potential spontaneous ignition of the material would continue to exist as material accumulated in Buildings 707,771 , 776/777, and 779, until Nuclear Material Safeguards Category III limits were reached in each building. At that point, additional continuous 24-hour material surveillance would be required in each building, until the material was removed. 


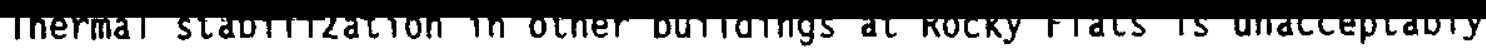
inefficient, because safety system upgrades and extensive testing would be required. These requirements have already been met in Building 707 .

Alternative methods of processing pyrophoric plutonium, such as sintering, cementation, vitrification, and lower temperature stabilization with chemical catalysts (as suggested in a public meeting) were considered unreasonable in this case, for a variety of reasons. Rocky Flats does not currently have the capability to sinter or vitrify the plutonium and could not make these processes operational in order to take action now to enhance safe storage at Rocky Flats. Vitrification may preclude or severely complicate options for ultimate disposition of plutonium oxide, making it an undesirable alternative at this time. It is not certain whether cementation would ensure a loss of pyrophoricity in the plutonium. Additionally, cementation may preclude or complicate options for future disposition. Technical questions exist associated with stabilization using chemical catalysts, such as whether small amounts of plutonium may remain pyrophoric. These, in addition to being an unproven and untested technology, make this option unacceptable.

While pyrophoric plutonium could be shipped to another site, this alternative was deemed unreasonable. Transportable quantities of potentially pyrophoric plutonium are minuscule, being limited to 0.032 grams per shipping container. Thus, this alternative would result in tens of thousands of shipments requiring many years to remove the material from Rocky $\mathrm{Flats.} \mathrm{The} \mathrm{time} \mathrm{required} \mathrm{to} \mathrm{repackage} \mathrm{and} \mathrm{conduct}$ 
the shipments would not enable Rocky flats to take action now to enhance safe storage at Rocky Flats.

DETERMINATION: Based on the information and analyses in the EA, DOE has determined that the proposed thermal stabilization of potentially pyrophoric plutonium in Building 707 at Rocky Flats does not constitute a major Federal action significantly affecting the quality of the human environment within the meaning of the National Environmental Policy Act of 1969. Therefore, an Environmental Impact Statement for the proposed action is not required.

Issued at Washington, DC, this $10^{\text {th }}$ day of February, 1994.

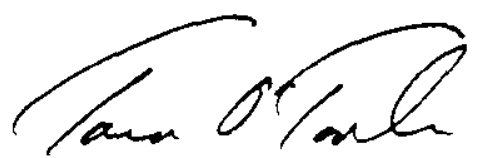

Tara O'Toole, M.D., M.P.H. Assistant Secretary

Environment, Safety and Health 